\title{
THE INFLUENCE OF HUMIDITY ON THE RESIDUAL ACTION OF BENZENE HEXACHLORIDE (BHC)
}

\author{
R. Penna, A.E.X. Oliveira, M.F.N. Ferreira, C. Johnson, A. Bosworth and \\ P.D. Marsden
}

\begin{abstract}
In controlled humidity chambers in the laboratory differences in the absorption velocity of $B H C$ were observed depending on the substrate sprayed. While BHC is no longer used in Chagas' disease control this data could have relevance to spraying houses in a control programme with other insecticides.
\end{abstract}

Key-words: Benzene Hexachloride(BHC). Residual activity on different natural substrates.

The application of BHC on the wall surfaces inside of houses was the primary method to control triatomine bugs which are vectors of Chagas' disease in Brazil. Residual activity of the insecticide BHC was studied on building materials taken from Mambai, Goias-Brazil ${ }^{4}$. Results of experiments in the field and laboratory suggested that higher mortalities coincide with higher ambient relative humidities. Data presented 1 and Nocerino ${ }^{3}$ demonstrated that old insecticide deposits of BHC had greater killing power at higher atmospheric humidities. The objective of this study is to demonstrate the residual insecticidal activity of BHC on different building materials in controlled humidity chambers in the laboratory.

\section{MATERIAL AND METHODS}

Two experiments were used to show the effect of humidity on the insecticidal activity of BHC, $30 \%$ gamma isomer, on laboratory reared, first instar nymphs of Dipetalogaster maximus. Nymphs were exposed to the vapor of $\mathrm{BHC}$ which were being released from the treated surface $(0.5 \mathrm{mg}$ of gamma $\mathrm{BHC} / \mathrm{m}^{2}$ ) of building materials taken from Mambai, Goias.

In the first experiment, six humidity chambers were prepared by using covered $30 \mathrm{~cm}$ glass dessicators with relative humidities $(\mathrm{RH})$ regulated in each chamber by concentrations of glyceral solutions in the bottom. The humidities were measured by a miniature thermocouple psychrometer. The test material was fired roof tile sprayed with BHC 20 months earlier. Treated tiles were placed on porcelain trays in faour chamber, three of which were calibrated at $50 \%, 60 \%$

Núcleo de Medicina Tropical e Nutrição e Departamento de Biologia Vegetal, Universidade de Brasília, Brasília, DF.

Address: Prof. Philip D. Marsden. NMTN/UnB. CP: $15-$ 3121, 70910 Brasilia, DF, Brasil.

Recebido para publicação em 31/01/91. and $80 \%, \mathrm{RH}$ respectively, and one chamber was left open to ambient conditions which ranged from $64 \%$ to 84\% RH. Four control chamber without treated tiles were set up in the same way. Mean temperature during the experiment was $22^{\circ} \mathrm{C}$ (range $21.5^{\circ} \mathrm{C}$ to $26^{\circ} \mathrm{C}$ ).

In the second experiment, six covered dessicator chambers were prepared for testing five different house construction materials which had been treated with BHC 24 months earlier. Fired roof tile, unfired mud brick, plaster with lime, plaster without lime and wood were placed on the porcelain trays in five chambers, only one substrate for each chamber. The sixth chamber used as the control had no substrate. All chambers were regulated to $90 \% \mathrm{RH}$.

The LT50 activity of the insecticide was measured by observing and recording the mortality of the nymphs in terms of lethal time in days at which $50 \%$ of any given population of bugs had died. Each chamber had three replicates. A replicate consisted of 10 unfed nymphs placed in a flat round tin $(5.4 \mathrm{~cm}$ in diameter and $8 \mathrm{~mm}$ deep) covered with fine nylon mesh netting. Three tins with bugs were spaced $5 \mathrm{~mm}$ from the netting to the test surface by cardboard rings. Observations of bug mortality were made for 30 days in each experiment. One-way analysis of variance using the LT50 values of each replicate within any given chamber was made in both experiments with the level of significance set at 5\%. Duncan's new multiple range method was used to test mean differences at a nominal 5\% level of significance.

\section{RESULTS}

In the first experiment, the mortality of nymphs in the test chambers with treated tiles was highest in the chamber with $80 \% \mathrm{RH}$, and lowest in the chambers with $50 \%$ and $60 \%$ RH (Table 1). The chamber with ambient humidity conditions had intermediate effects on bug mortality. Significant differences in the mean LT50s are caused by different humidities in the test chambers. Survival of bugs in the control chambers without treated surfaces was similar to survival in the low humidity (50-60\% RH) chambers. 
Penna $R$, Oliveira $A E X$, Ferreira MFN, Johnson C, Bosworth A, Marsden PD. The influence of humidity on the residual action of benzene hexachloride (BHC). Revista da Sociedade Brasileira de Medicina Tropical 24: 115-116, abr-jun, 1991

Table 1 - The effect of relative humidity on the insecticial activity of BHC applied as a residual insecticide on roof tile about 20 months before this test.

\begin{tabular}{lcccc}
\hline & \multicolumn{2}{c}{ Relative humidity } & Ambient \\
& $50 \%$ & $60 \%$ & $80 \%$ & $(64-83 \%)$ \\
\hline Test LT50 & $*$ & $*$ & $4.3 \pm 0.5$ & $15.0 \pm 2.4$ \\
Test \% alive & 93.3 & 100 & 0 & 0 \\
Control LT50 & $*$ & $*$ & $*$ & $*$ \\
Control \% alive & 96.7 & 100 & 100 & 100 \\
\hline
\end{tabular}

(*) LT50 not reached in 30 days.

$1_{\mathrm{F}}$ is significant at $<.005 \%$; the mean LT50s are significantly different using the multiple range test at the nominal $5 \%$ level. $2 \%$ alive after 30 days.

Table 2 - LTSO values caused by the residual insecticide activity of BHC which had been applied to different construction materials about 24 months before this test. Humidity was kept at a constant $90 \%$ RH.

\begin{tabular}{|c|c|c|c|c|}
\hline \multirow[b]{2}{*}{ Roof tile } & \multicolumn{4}{|c|}{ Mean LT50 values for each construction material } \\
\hline & Wood & $\begin{array}{c}\text { Mud brick } \\
\text { (unfired) }\end{array}$ & $\begin{array}{l}\text { Mud plaster } \\
\text { (no lime) }\end{array}$ & $\begin{array}{l}\text { Mud plaster } \\
\text { (with lime) }\end{array}$ \\
\hline $4.3 \pm 0.5$ & $8.0 \pm 0.9$ & $9.7 \pm 1.2$ & $10.0 \pm 1.4$ & $14.3 \pm 4.5$ \\
\hline
\end{tabular}

$\mathrm{F}=5.30$; the probability of a larger $\mathrm{F}$ is $<.025$.

Mean LT50 values which are underlined by the same line are not significantly different using the nominal significance level of .05 for the multiple range test.

The LT50 mortality of nymphs in experiment two varied significantly with different construction materials treated with $\mathrm{BHC}$ held in test chambers maintained at $90 \%$ RH (Table 2). F was significant with the probability of a larger $F$ at $\leq 0.25$. Comparison of means are shown by ranking the substrates from the fastest killing power to the substrate with the slowest killing strenth. With the nominal level of significance set at the .05 level for the multiple range test, average LT50 means which were similar and not significantly different are underlined with a single line.

\section{DISCUSSION}

The absorption of insecticide by mud surfaces results in a rapid decay in its residual action ${ }^{13}$. It has been observed that at times of high humidities, higher mortality of insects exposed to sprayed surfaces occurs $^{3} 4$. Our results confirm these observations, showing that the actions of $\mathrm{BHC}$ can be recovered at high humidities even two years after spraying.

The insecticide does not degrade on contact with the surface, but penetrates inside the material ${ }^{2}$. A high humidity brings the insecticides to the surface, exposing the insects to a greater amount of the compound 3 . Fomm and Gandini 1 studying the absorption of gamma BHC by different kinds of mud in the field and. used water sprays to regenerate BHC activity. Nocerino $^{3}$ suggests spraying water on house walls to reactivate insecticides, and the present work again points to this possibility.

Our data on the influence of the surface agree with those obtained by other authours 12 , which show differences in absorption velocities of BHC in different types of mud or differences in the persistence of insecticide activity in different materials. The composition of the surface plays an important role in the persistence of insecticide activity ${ }^{4}$.

\section{RESUMO}

Em câmaras de umidade controlada foi observada diferença na velocidade de absorçáo do BHC relacionada ao substrato borrifado. Embora não seja mais utilizado o BHC pelo Controle da Doença de Chagas no Brasil, estes dados podem ser relevantes para outros inseticidas usados em programas de controle.

Palavras-chaves: Hexacloro-benzeno (BHC). Atividade residual sobre diferentes substratos naturais.

\section{REFERENCES}

1. Fomm AS, Gandini P. Absorção do isomero gama do BHC por diferentes tipos de barro. Avaliação biológica com Triatoma infestans. Revista Brasileira de Malariologia e Doenças Tropicais 23: 111-134, 1971.

2. Hadaway AB, Barlow F. Studies on aqueous suspensions of insecticides. Part III: Factors affection the persistence of some synthetic insecticides. Bulletin of Entomological Research 43: 291-311, 1952.

3. Nocerino F. Afloramiento de cristales de insecticidas con el humedecimiento en las superficies rociadas. Boletin de la Dirección de Malariologia y Saniamiento Ambiental 21: 54-58, 1981.

4. Penna R, Bosworth A, Brasil IA, Marsden PD. Persistência da atividade residual do BHC na superficie de diferentes materiais de construção. Revista da Sociedade Brasileira de Medicina Tropical 17: 95-99, 1984. 